\title{
Regulating Related Party Transactions During the COVID-19 Crisis
}

\author{
Anna Toniolo*
}

\section{Abstract}

Related party transactions ("RPTs") are frequently used as a tool for siphoning off value from a company, but they can also be an efficient instrument for assisting firms. The trade-off between stopping value-decreasing RPTs and promoting value-increasing RPTs requires lawmakers to seek an optimal balance, relying on several contingent factors. This paper highlights the strong interdependency between RPTs regulation and economic changes. After the 2008 crisis, policymakers have enhanced minority shareholders' control over RPTs, considering their involvement as the most effective safeguard against tunnelling. During the COVID-19 crisis, governments have introduced exemptions to the rules on RPTs, even if they might weaken minority shareholders' protection. The reason is that firms face dramatic liquidity shortfalls due to the pandemic, and RPTs can be a vehicle for providing finance to distressed companies, avoiding a wave of bankruptcies that would be dangerous for the economy. Thus, RPTs regulation has been tweaked for adapting to the new economic environment, and these legal changes, in turn, could affect the economic recovery.

Keywords: Controllers, Corporate Governance, Economic crisis, Liquidity Lifeline, Minority Shareholders

\footnotetext{
* Post Doc Research Fellow at University of Trento, Italy; anna.toniolo@unitn.it.
} 


\section{Introduction}

Related Party Transactions [hereinafter 'RTPs'] are a typical instrument for extracting wealth from a company, notably resulting in the expropriation of minority shareholders. At the same time, such transactions might be sound business exchanges that bring significant benefits for enterprises.

Between preventing value-reducing RPTs and allowing valuecreating RPTs, there is a tension that cannot be resolved. Therefore, lawmakers should try to find the optimal balance for these conflicting goals on the policy level, considering that the suitable trade-off varies between countries, companies, and time since many context-specific factors determine the best solution for any given situation. This article argues that the right trade-off crucially depends on and should adapt to the economic changes.

In the aftermath of the 2008 financial crisis, policymakers have focused on improving non-controlling shareholders' control over RPTs, since they found that minority investors lacked adequate tool for protecting themselves against abusive RPTs. On the contrary, amid the COVID-19 pandemic, governments have enacted relaxation or suspension of the RPTs' rules that might reduce minority shareholders oversight of RPTs. Due to the economic crisis that has followed the COVID-19 outbreak, many companies suffer from a severe liquidity shortage. Thereby, it has become essential for lawmakers to adopt measures to provide the funding necessary to ensure that otherwise solvent enterprises do not go bankrupt. In response to this current primary need of the economy, RPTs regulation has been tweaked to incentivize controllers to finance their distressed firms, even at the cost of increasing the risk of abuse. This shows how searching for a balance in the RPTs discipline is ongoing as the economy changes.

In the beginning, the article defines related party transactions, distinguishes between value-decreasing and value-increasing RPTs, and it describes the different legal strategies used for regulating RPTs. It further explains how after the 2008 financial crisis, the policymakers' effort has been on enhancing shareholders' oversight of RPTs. The author also focuses on the peculiar features of the 
economic crisis triggered by COVID-19, its impacts on the enterprises, and the measures adopted during the emergency. Finally, the paper examines the exemptions to the RPTs' regulation enacted amid the pandemic and their rationale.

\section{Law and Economics of Related Party Transactions}

Related party transactions refer to transactions between a corporation and a "related party"1, a term of art that comprises counterparties who can influence corporate decision-makers, such as directors, managers, controlling shareholders, or controlling entities (so-called "controllers").

According to the International Financial Reporting Standards, the definition of RPTs encompasses every "transfer of resources, services or obligations between a [corporation] and a related party, regardless of whether a price is charged" 2 . Hence, dealings falling under this definition involves a wide range of transactions, including purchases or sales of assets, goods or services by related parties, loans, company guarantees in favour of its parent, transactions with close relatives of managers or with companies owned by their families, compensation agreements, retirement and severance packages, etc.

RPTs are, per se, legitimate business transactions, or they have at least the appearance of a legitimate business transaction ${ }^{3}$. Nevertheless, they involve the very intuitive risk ${ }^{4}$ of an influential manager or a controlling shareholder transacting on terms less favorable for the company than could be obtained in an arm's length negotiation, so that the transaction is entered into on unfair terms and it translates

1 International Accounting Standards Board, International Accounting Standard No. 24.

2 IAS 24, supra note 1.

${ }^{3}$ L. Enriques, Related Party Transactions: Policy Options and Real-World Challenges (With a Critique of the European Commission Proposal), EURPOEAN BUSINESS ORGANISATION LAW REVIEW 12 (2015).

${ }^{4}$ R. La Porta et al., The law and economics of self-dealing, JOURNAL OF FINANCIAL ECONOMICS 88(3) (2008). 
into loss for the company ${ }^{5}$. In other words, when vested with discretionary powers, the controller will naturally tend to set the dealing terms in such a way to foster his interest at the expense of that of the company ${ }^{6}$. For this reason, RPTs are viewed as one of the most severe breaches of good corporate governance ${ }^{7}$.

\subsection{Tunneling and Propping through RPTs}

RPTs are a standard instrument for "tunnelling"8, which covers all forms of misappropriation of value (assets, cash flows, or the company's equity itself) by corporate insiders. It must be clarified that on one side, RPTs do not necessarily involve tunnelling, and on the other, tunnelling can be the outcome of behaviour not involving RPTs. For example, direct dilution of the investors' claims is a form of tunnelling that does not necessarily involve RPTs, since dilution can be implemented unilaterally by the corporate controllers. The proceeds of tunnelling (i.e. the value extracted from the corporation), in turn, are known as private benefits of control$^{9}$, which identify all

${ }^{5}$ A. Habib et al., Related Party Transactions and Stock Price Crash Risk: Evidence From China, InTERnATIONAL JOURNAL OF ACCOUNTING (2019); Id., Related Party Transactions and Audit Fees: Evidence from China, 14, JOURNAL OF INTRERNATIONAL ACCOUNTING RESEARCH (2015); Y. L Cheung et al., Buy high, sell low: How listed firms price asset transfers in related party transactions, 33(5), JOURNAL OF BANKING \& FINANCE, Elsevier, 914(2009).

6 A. M. Pacces, Rethinking Corporate Governance: The LAW And ECONOMICS OF CONTROL POWERS, Routledge Research in Corporate Law,1, 233-234 (2012).

7 World Bank, Protecting Minority Shareholders: Frequently Asked Questions, (May 2019),

https://www.doingbusiness.org/en/data/exploretopics/protectingminority-investors/faq; E. A. Gordon et al., Related Party Transactions: Associations with Corporate Governance and Firm Value, EFA 2004 Maastricht Meetings Paper No. 4377, AFA 2006 Boston Meetings Paper (2004).

8 S. Johnson et al., Tunneling, 90 AM. ECON. REV. 22, 22 (2000); A. Atanasov et al., Law And Tunneling, 37 JOURNAL OF CORPORATION LAW, 1 (2011); id., Unbundling and Measuring Tunneling, U. ILL. L. REV. 101 (2014); S. Djankov et al., The law and economics of self-dealing, 88 JOURNAL OF FINANCIAL ECONOMICS, 430-465 (2008).

${ }_{9}^{9}$ M. J. Barclay \& C. G. Holderness, Private Benefits of Control in Public Corporations, 25 JJFE 371, 374 (1989). 
utilities accruing to a controller that she does not share with (other) investors on a pro-rata basis ${ }^{10}$. In companies with concentrated ownership - which is the most common ownership structure around the world ${ }^{11}$ - abusive RPTs consist mainly of expropriations by controlling shareholders to the detriment of minority shareholders ${ }^{12}$. Transactions that result in the expropriation of non-controlling shareholders are always inefficient for the company that enters into them, regardless of whether the related party gains more than the company loses ${ }^{13}$. However, despite their vulnerability to tunnelling by corporate insiders, RPTs are never completely prohibited, basically for two reasons.

Firstly, sometimes they are simply unavoidable. For example, prohibiting managerial compensation would be absurd since no one would agree to work for the corporation for free ${ }^{14}$. Intragroup transactions ['IGTs'], as well, are a matter of routine almost inevitable within an integrated group ${ }^{15}$. Besides, they are often economically

10 Pacces supra note 6 at 235.

11 OECD, Related Party Transactions and Minority Shareholder Rights, OECD Publishing (2012); Z. Goshen \& A. Hamdani, Corporate Control and the Regulation of Controlling Shareholder 24, THE LAW AND FINANCE OF RELATED PARTY TRANSACTIONS, L. Enriques \& T. H. Tröger eds., (2019); J. R. Franks \& C. Mayer, Evolution of Ownership and Control Around the World: The Changing Face of Capitalism, 33 Working Paper (2017).

12 S. Y. Kang, Optimally Restrained Tunneling: The Puzzle of Controlling Shareholders' "Generous" Exploitation in Bad-Law Jurisdictions, in THE LAW AND FinANCE OF RELATED PARTY TRANSACTIONS 287 (L. Enriques \& T. H. Tröger eds., 2019).

13 A. M. Pacces, Procedural and Substantive Review of Related Party Transactions. The Case for Noncontrolling Shareholder-Dependent Directors, THE LAW AND FINANCE OF RELATED PARTY TRANSACTIONS 182 (L. Enriques \& T. H. Tröger eds., 2019).

14 L. Enriques et al., Related PARTy Transactions, THE ANATOMY OF Corporate LAW: A COMPARATIVE AND FunCTIONAL APPROACH 146 (R. Kraakman et al. eds., 2017).

15 J. Damman, Related Party Transactions and Intragroup Transactions, THE LAW AND FINANCE OF RELATED PARTY TRANSACTIONS 218 (L. Enriques \& T. H. Tröger eds., 2019); K. J. Hopt, Groups of Companies. A Comparative Study on the Economics, Law and Regulation of Corporate Groups, ECGI 
beneficial. Even if the individual transaction is not fair to the subsidiary, synergies arising from repeated RPTs or lower transactions cost could make both the parent and its subsidiaries better off in the longer run ${ }^{16}$.

Secondly, RPTs can be efficient transactions conducted in the best interest of the individual company, which might even create value for all parties involved and the society ${ }^{17}$. RPTs can replace market dealings ${ }^{18}$, ensuring transaction cost savings ${ }^{19}$. Compared to arm's length transactions, RPTs facilitate better coordination of the different activities, and they allow for negotiation and renegotiation cost savings. For small firms - which face disproportionate transaction costs when dealing with unconnected market participants -, directors, officers, and controlling shareholders, are often the only parties they can transact with. Moreover, outsiders may be unable to evaluate the company's prospects or be subject to the revelation of trade secrets or confidential plans that companies would better keep for themselves. In contrast, insiders may know the company better than an unrelated but distrustful party ${ }^{20}$. Finally,

(2015); T. H. Tröger, Corporate Groups, A German's European Perspective, SAFE WORKING PAPER NO. 66 (2014); P.-H. Conac, Director's Duties in Groups of Companies - Legaliyzing the Interest of the Group at the European Level, ECFR (2013).

${ }^{16}$ Enriques (2015) supra note 3.

${ }^{17}$ D. H. Downs et al., Related Party Transactions and Firm Value: Evidence from Property Markets in Hong Kong, Malaysia and Singapore, 52 J. REAL ESTATE FINAN. ECON. 408 (2016); R. M. K. Wong et al., Are Related-Party Sales Value-Adding or Value-Destroying? Evidence from China, 26 J. INT'L FINAN. MGMT. \& ACCT. 1 (2015); M. Ryngaert \& S. Thomas, Not All Related Party Transactions (RPTs) Are the Same: Ex-ante Versus Ex-post RPTs, $50 \mathrm{~J}$. ACCT. RES. 845 (2012).

${ }^{18}$ K. S. Kim, Related Party Transactions in East Asia,THE LAW AND FINANCE OF RELATED PARTY TRANSACTIONS 287 (L. Enriques \& T. H. Tröger eds., 2019). ${ }^{19}$ R. H. Coase, The nature of the firm, 4 ECONOMETRICA N. S. 386-4040 (1937). ${ }^{20}$ Damman, supra note 15. 
RPTs could provide for funding that would not be available on regular capital markets ${ }^{21}$.

It could even happen that an RPT is entered into favourable terms for the corporation and unfavourable ones for the related party if the latter has an interest in supporting the former (so-called "propping"22), which might be even only to keep extracting private benefits of control from it in the future ${ }^{23}$. A private controller can equally engage in propping, either using a partly-owned subsidiary to prop up a distressed one or injecting some money from her own pockets ${ }^{24}$. When the assistance comes from other sister firms within the corporate group, it is simply the flip side of tunnelling because resources are transferred from one company within the group (the victim of tunnelling) to another (the beneficiary of propping). When the controlling shareholder herself supports control firms, this benefits both minority investors and creditors, and, usually, it does not decrease social welfare in the private sectors ${ }^{25}$. For example, a controlling shareholder might use RPTs to "prop up" a controlled firm on the verge of bankruptcy by lending to it at a below-market (or even zero) interest rate.

${ }^{21}$ R. W. Masulis et al., Family Business Groups around the World: Financing Advantages, Control Motivations, and Organizational Choices, 24 RevIEW OF FinANCIAL STUDIES, 3556 (2011).

${ }^{22}$ E. Friedman et al., Propping and Tunneling, 31 J. COMP. ECON., 4, 732 (2003); M. Jian \& T.J. Wong, Propping through Related Party Transactions, REVIEW OF ACCOUnTING STUdies, 70-105 (2010); Y.L. Cheung et al., Tunneling, Propping, and Expropriation: Evidence from Connected Party Transactions in Hong Kong, 82 J. FIN. ECON, 343 (2006).

${ }^{23}$ Friedman, supra note 22.

${ }^{24}$ L. Enriques \& T. H. Tröger, The Law and (Some) Finance of Related Party Transactions. An Introduction, THE LAW AND FINANCE OF RELATED PARTY TRANSACTIONS 5-6 (L. Enriques \& T. H. Tröger eds., 2019).

${ }^{25}$ C. J. Milhaupt \& M. Pargendler, Related Party Transactions in State-Owned Enterprises. Tunneling, Propping, and Policy Channeling, THE LAW AND FinANCE of Related PARTY TRANSACTIONS 248 (L. Enriques \& T. H. Tröger eds., 2019). 


\subsection{Legal Strategies for Regulating RPTs}

Corporate lawmakers resort to a wide range of legal strategies to prevent RPTs from being used for tunnelling purposes without stifling beneficial transactions. However, they mainly fall into three groups: mandatory disclosure, procedural requirements, and ex-post judicial review.

Mandatory disclosure is a widely used technique to address RPTs ${ }^{26}$, even though the regulatory intensity varies ${ }^{27}$. Mandatory disclosure alerts shareholders and the market to RPTs, but in isolation is insufficient to prevent tunnelling ${ }^{28}$. Its importance is more in supporting internal decision-makers independence. They will act more assertively if they know the RPT they may approve will be subject to public scrutiny and facilitate private and public enforcement against tunnelling 29 .

Most jurisdictions provide for procedural requirements when entering into RPTs. The primary method is the board approval and particularly the approval by disinterested or independent directors. The involvement of disinterested/independent directors has several virtues: compliance is (relatively) cheap; fair, value-increasing transactions are likely to be approved; disinterested directors might question suspect related-party transactions ${ }^{30}$. The high costs are specular. Primarily, directors can play an influential role in protecting the minority shareholders only if they can be expected to act genuinely independently from controllers ${ }^{31}$. Nevertheless, substantial independence is not guaranteed since, for the most part, they are selected with the (interested) consent of top executive officers, controlling shareholders, or both ${ }^{32}$. Lastly, disinterested directors might have insufficient knowledge of a company's

${ }^{26}$ Enriques (2015), supra note 3.

${ }^{27}$ Enriques et al., supra note 14 .

${ }^{28}$ Y. L. Cheung et al., Buy high, sell low: How listed firms price asset transfers in related party transactions, JOURNAL OF BANKING \& FINANCE (2009).

${ }^{29}$ Enriques et al., supra note 14, at 147.

${ }^{30} \mathrm{Id}$. at 153.

${ }^{31}$ Enriques \& Tröger, supra note 24, at 11.

${ }^{32}$ Enriques et al., supra note 14, at 153. 
business and organizational structures that would allow insiders to opportunistically filter information, thereby distorting the decisionmaking process to their advantage ${ }^{33}$.

As an alternative or complement to disinterested board approval of RPTs, some jurisdictions require or encourage shareholders' approval, particularly "Majority Of the Minority" [hereinafter 'MOM'] approval. After all, while outside directors are at best disinterested, shareholders are affirmatively interested in preserving corporate value ${ }^{34}$. Thereby, MOM could empower non-controlling shareholders to look after their interests, negotiating improved terms ${ }^{35}$. However, there are some concerns about MOM approval. It is a cumbersome and costly instrument, which is why jurisdictions that provide for MOM approval usually do so only for RPTs above a given size $^{36}$. Shareholders often have neither the right incentives nor the necessary expertise ${ }^{37}$. Its reasoning runs counter to the logic of delegated management that characterizes the corporate form ${ }^{38}$.

Since directors are usually more knowledgeable about business transactions, whereas shareholders have better incentives to stop tunnelling to their disadvantage, synergies could derive from the combination of the two procedural safeguards ${ }^{39}$.

Jurisdictions usually rely also on ex-post judicial review for tackling RPTs. There are various ex-post standard-based reviews of RPTs, but they can be divided into procedural reviews or substantive reviews. The former would validate the transaction if it were approved with due process. The latter evaluates the RPT in comparison with a market transaction concluded at arm's length ${ }^{40}$. Jurisdictions may also apply different standards of review to different RPTs. For

${ }^{33}$ Enriques (2015), supra note 3, at 21; Enriques \& Tröger, supra note 24, at 9.

${ }^{34}$ Enriques et al., supra note 14 , at 156.

35 Z. Goshen, The Efficiency of Controlling Corporate Self-Dealing: Theory Meets

Reality, 91 CALIF. L. REV. 393, 402(2003).

36 Enriques (2015), supra note 3.

${ }^{37} \mathrm{Kim}$, supra note 18.

38 Enriques et al., supra note 14, at 156.

39 Pacces (2019), supra note 13, 200; Enriques (2015), supra note 3, at 22.

40 Pacces (2019), supra note 13. 
example, corporate law in many countries provides for more lenient standards when RPTs also qualify as intra-group transactions, given they are routine, repeat transactions, the individual review of which by courts would be practically incompatible with the very group business form ${ }^{41}$. In any case, functionally, a standard of review needs to be combined with effective enforcement. Yet, the strictness of enforcement and courts' ability to understand and evaluate business transactions vary significantly ${ }^{42}$.

Policymakers have responded in many different ways for dealing with RPTs. However, none of the techniques described above, nor a combination of them, can guarantee that only value-increasing RPTs proceed while value-decreasing transactions are stopped. This, because there is an inevitable trade-off between promoting the former and curbing the latter. Therefore, the goal is to identify an optimal regime for RPTs in terms of effectiveness (i.e. ability to stop value-decreasing RPTs) and efficiency (i.e. allowing value-increasing RTPs to proceed $)^{43}$. The effectiveness and the efficiency of a strategy vary between countries, companies, and time since they are strictly correlated to contextual factors (like geographical and cultural differences, corporations' industry and size), institutional infrastructures, economic and political environment 44. A fundamental role is played by governance models, governance practices (like board approval, independent directors' involvement,

${ }^{41}$ Enriques (2015), supra note 3, at 26.

${ }^{42}$ Enriques et al., supra note 14, at 161 . For Delaware case law see Weinberger v. UOP, 7, Corp. L. Rev. 195, 196 (1984); Kahn v. Lynch Communication Systems, Inc, Supreme Court of Delaware, 1994, 638 A.2d 1110; Kahn v. M \& F Worldwide Corp., in 88 A.3d 635 ss. (Del. 2014). In Italy, see the "Parmalat Case": Trib. Parma, 29 marzo 2013 (decr.), Giur. comm., 2014, II, pp. 95 ss.; Trib. Parma, 11 novembre 2013 (decr.); App. Bologna, 26 maggio 2014 (decr.), Giur. comm., 2015, II, pp. 1012 ss.; and the "Fondiaria-Sai Case": Trib. Milano, 20 dicembre 2013 (ord.), nonché Trib. Milano, 20 febbraio 2015 (ord), www.giurisprudenzadelleimprese.it. 43 Pacces (2019), supra note 13.

${ }^{44}$ M. Pizzo, Related party transactions under a contingency perspective, 17 JOURNAL OF MANAGEMENT \& GOVERNANCE No. 2, 319-320 (2013). 
external appraisal, etc.), and ownership structure 45 , which differ among countries as well, preventing from automatically translating to others or considering as generally valid conclusion supported by empirical evidence in one jurisdiction ${ }^{46}$. Finally, no regulation of RPTs can succeed in impeding tunnelling in the absence of effective enforcement mechanisms ${ }^{47}$. As a result of this, RPTs rules should not be examined in isolation on a stand-alone basis, but it is necessary to evaluate their relations with these factors and the manners in which they are enforced by regulators and adhered to by market participants.

\section{RPTs Regulation after the 2008 Crisis}

The 2008 financial crisis showed some significant shortcomings in corporate governance, especially of financial institutions 48 . According to several authorities, failures of corporate governance were a vital cause of the crisis ${ }^{49}$. Notably, it represented the failure

${ }^{45}$ M. Lemmon, \& K. V. Lins, Ownership structure, corporate governance, and firm value: Evidence from the East Asian Financial Crisis, JOURNAL OF FINANCE, 58, 1445-1468 (2003); M. Bertrand et al., Ferreting out tunneling: An application to Indian business groups, QUARTERLY JOURNAL OF ECONOMICS, 117(1), 121-148 (2002); M. Kang, The Association between Related-Party Transactions and Control-Ownership Wedge: Evidence from Korea, 29 PACIFIC-BASIN FIN. J. 272 (2014).

${ }^{46}$ D. W. Puchniak \& U. Varottil, Related Party Transactions in Commonwealth Asia. Complexity Revealed, THE LAW AND FINANCE OF RELATED PARTY TRANSACTIONS 343-344 (L. Enriques \& T. H. Tröger eds., 2019).

47 Enriques (2015), supra note 3.

${ }^{48}$ Directorate for Financial and Enterprise Affairs OECD Steering Group on Corporate Governance, Corporate Governance and the Financial Crisis. Conclusions and emerging good practices to enhance implementation of the Principles, OECD publishing (2010).

49 FINANCIAL CRISIS INQUIRY COMMISSION, FINAL REPORT OF THE NATIONAL COMMISSION ON THE CAUSES OF THE FINANCIAL AND ECONOMIC CRISIS IN THE UNITED STATES, (2011); J. De Larosière, Report of the High-Level Group on Financial Supervision in the EU, (2009); ASSOCIATION OF CHARTERED CERTIFIED ACCOUNTANTS, CLIMBING OUT OF THE CREDIT CRUNCH. ASSOCIATION OF CHARTERED CERTIFIED ACCOUNTANTS, LONDON, (2008); G. 
of the shareholder-owner model who contributes to the company's long-term viability ${ }^{50}$. Most of the incentives encouraged financial institutions' managers to act on a short-term perspective and make as much profit as possible to the detriment of credit quality and prudence ${ }^{51}$. Shareholders as well showed little interest in the longterm governance objectives of the businesses in which they invested. Instead, they seemed to encourage excessive risk-taking given their relatively short (or even very short) investment horizons ${ }^{52}$. Thus, appropriate shareholder engagement has started to be viewed as "the linchpin of an effective corporate governance framework"53.

Not surprisingly, RPTs have been at the centre of the debate on corporate governance that followed the financial crisis. Minority shareholder's protection and engagement are highly relevant in relation to the role of shareholders in corporate governance ${ }^{54}$, and RPTs - especially after the corporate scandals of the $2000 s^{55}$ - are considered the primary vehicle for controlling shareholders to extract private benefits of control to the detriment of minority shareholders56. That is why "Financial economists, legal scholars, the Organization for Economic Co-operation and Development, and

Kirkpatrick, Corporate governance lessons from the financial crisis, OECD PUBLISHING, (2009).

50 European Commission, Green PAPER. Corporate governance iN FINANCIAL INSTITUTIONS AND REMUNERATION POLICIES, BRUSSELS, (2010).

51 J. De Larosiere, Report of the High-Level Group on Financial Supervision EU, BRUSSELS (25 February 2009).

52 European Commission, supra note 50.

53 C. Van der Elst \& E. P.M. Vermeulen, Europe's Corporate Governance Green Paper: Rethinking Shareholder Engagement, THE EUROPEAN FINANCIAL MARKET IN TRANSITION, 200 (H. S. Birkmose et al. eds., 2012).

54 L. ENRIQUES ET AL., THE BASIC GOVERNANCE STRUCTURE: MiNORITY SHAREHOLDERS AND NON-SHAREHOLDER CONSTITUENCIES, THE ANATOMY of CORPORATE LAW. A COMPARATIVE AND FUNCTIONAL APPROACH 79 (R. Kraakman et al. eds., 2017).

${ }^{55}$ In the U.S.: In Re Enron 235 F Supp. 2d 549 U.S (2002) and SEC v WorldCom Inc 273 F Supp 2d 431 (2003). In Italy, see the Parmalat case supra note 42.

56 European Commission, Green Paper. The EU corporate governance framework, Brussels, 5.4.2011 COM(2011) 164 final. 
others have urged lawmakers to subject certain self-dealing transactions to a vote by 'disinterested' shareholders" 57 . Policymakers have also started to consider direct minority shareholder involvement as the most effective procedural safeguard against tunnelling. Therefore, an increasing number of countries have provided or tried to provide for such a requirement with respect to larger, non-routine transactions ${ }^{58}$. This can be observed in the measures taken in both India and the EU.

\subsection{The European Union}

At the European Union level, in 2014, the Commission presented a proposal of directive amending Directive 2007/36/EC (so-called "Shareholder rights Directive", or "SRD") aimed at improving shareholders' control over RPTs. The Commission claimed that RPTs create the opportunity to appropriate value belonging to the company to the detriment of shareholders and notably minority shareholders. Additionally, it found that minority investors still lacked access to sufficient information and adequate tools to protect themselves against abusive RPTs. For this reason, the Proposal required listed companies to submit significant transactions to a vote by the shareholders in a general meeting, not allowing the company to conclude the transaction before the shareholders' approval ${ }^{59}$.

This rule received several critiques. First, shareholders should be involved only on an exceptional basis since calling a shareholder meeting to affirm the corporation's significant transactions with its

57 A. Hamdani \& Y.Yafeh, Institutional Investors As Minority Shareholders, THE LAW AND FINANCE OF RELATED PARTY TRANSACTIONS 137 (L. Enriques \& T. H. Tröger eds., 2019).

${ }^{58}$ Enriques (2015), supra note 3, at 17; Enriques \& Tröger, supra note 24, at 12; Enriques et al., supra note 14, at 156-57.

${ }^{59}$ European Commission, Proposal for a Directive of the European Parliament and of the Council amending Directive 2007/36/EC as regards the encouragement of long-term shareholder engagement and Directive 2013/34/EU as regards certain elements of the corporate governance statement, Brussels, 9.4.2014 $\operatorname{COM}(2014)$, art. 9c(2). 
dominant shareholder is particularly expensive ${ }^{60}$. Second, it would slow down corporate decisions, and it could inadvertently give sensitive information to a competitor ${ }^{61}$. Third, it could transfer too many powers from boards to shareholders, giving minority shareholders an unwarranted potential for applying pressure ${ }^{62}$. Fourth, approval would be granted at the end of a negotiation process that member states were free to leave in the hands of interested agents when any other alternative might be worth less than the transaction itself ${ }^{63}$. Fifth, the proposed rule offered a single model irrespective of ownership structure and different national experiences ${ }^{64}$. Yet, alternative arrangements could work more effectively where the particularities of the corporate law environment are such that the regulation creates high costs 65 . Finally, the rule rested on the contestable presumption of minority shareholders' willingness and capacity to serve as effective

${ }^{60}$ C. Di Noia, European Company Law and Related Party Transactions. The EU legal framework, in CONVEGNO DI DIRITTO SOCIETARIO EUROPEO E OPERAZIONI CON PARTI CORRELATE, (2014); T. H. Tröger, Corporate groups: A German's European perspective, SAFE Working Paper, No. 66, Goethe University Frankfurt, SAFE, 29 (2014).

61 Business Europe and European Issuers, Business message on the upcoming committee vote on the shareholder rights proposal, 28 April 2015, https://www.businesseurope.eu/sites/buseur/files/media/imported/ 2015-00342-E.pdf.

62 European Banking Federation, EBF comments on the Revision of the Shareholders' Rights Directive, 23 September 2014, http://www.ebffbe.eu/position/ebf-comments-revision-shareholders-rights-directiveremuneration-related-party-transactions/.

${ }^{63}$ Enriques (2015), supra note 3, at 32.

${ }^{64}$ Di Noia, supra note 60; Business Europe and European Issuers, Business message on the upcoming committee vote on the shareholder rights proposal, (2015),

https://www.businesseurope.eu/sites/buseur/files/media/imported/ 2015-00342-E.pdf.

65 T. H. Tröger, Corporate fgroups: A German's European perspective, (SAFE Working Paper, No. 66, Goethe University Frankfurt, SAFE,p. 33(2014); H. Fleischer, Related Party Transactions bei börsennotierten Gesellschaften: Deutsches Aktien(konzern)recht und Europäische Reformvorschläge, 45 Betriebs-Berater 2691, p. 2696, 2014). 
counterweights to controlling shareholders' detrimental influence when vested with a right to vote on RPTs ${ }^{66}$. Nevertheless, there is a variety of minority shareholders and not all of them have the capability or the incentives for exercising an active role ${ }^{67}$. Moreover, MOM approval might function differently in the presence of different shareholders ${ }^{68}$.

Given the strong disapproval surrounding the RPTs' regulation, later presidency compromise texts ${ }^{69}$ and the European Parliament Proceedings' outcome ${ }^{70}$ altered the initial proposal, no longer setting a uniform European standard ${ }^{71}$. More in details, new Article 9c of the SRD - introduced by Directive (EU) 2017/828 of the European Parliament and of the Council of 17 May 2017 amending Directive 2007/36/EC as regards the encouragement of long-term shareholder engagement ("SRD2") - leaves discretion to the member states in determining whether material RPTs are to be approved by the board, the shareholders or the supervisory body. The final rule is the outcome of a severe retreat from the European Commission's initial

66 T. H. Tröger, Corporate groups: A German's European perspective, (SAFE Working Paper, No. 66, Goethe University Frankfurt, SAFE, 2014p. 29, 2014).

67 T. Strand, Short-termism in the European Union, 22 COLUM. J. EUR. L., 15, 48 (2015-2016).

68 E. B. ROCK, InSTITUTIONAL INVESTORS IN CORPORATE GOVERnANCE, OXFORD HANDBOOK OF CORPORATE GOVERNANCE(2018); Pacces, supra note 44; Hamdani \& Yafeh, supra note 57, 136; E. B. Rock, Majority of the Minority Approval in a World of Active Shareholders, THE LAW AND FINANCE OF RELATED PARTY TRANSACTIONS 105 (L. Enriques \& T. H. Tröger eds., (2019).

${ }^{69}$ Interinstitutional File 2014/0121 (COD), the Presidency compromise text Brussels, November 10, 2014, 13758/14; the Presidency compromise text Brussels, December 5, 2014, 15647/14; the Presidency compromise text, Council of the European Union, January 14, 2015, 5215/15 [Presidential Compromise Proposal].

70 Interinstitutional File 2014/0121 (COD), Brussels, July 22, 2015, Outcome of the European Parliament's proceedings.

${ }^{71} \mathrm{M}$. Roth, Related party transactions: board members and shareholders. The European Commission proposal and beyond, (2016), available at SSRN: https://ssrn.com/abstract=2710128. 
proposal, which imposed shareholders' approval as a mandatory procedural requirement ${ }^{72}$. However, the process that lead to the adoption of the SRD2 gives clear evidence that the RPTs discipline is not consistent with standardization and harmonization of rules, requiring rather a flexible approach that allows adapting firstly to different corporate governance models.

\subsection{India}

A similar evolution of the RPTs regulation can be seen in India. In the Indian legal system, which is characterized by concentrated ownership and the widespread use of company groups, RPTs are very common and significant. The financial crisis and some scandals, such as the Satyam fraud of late 2008, which involved abusive RPTs approved by independent directors, suggested the need for further measures aimed at protecting minority shareholders ${ }^{73}$. Thus, in 2013 a new Companies Act has been adopted, replacing the 1956 Companies Act.

The Companies Act was "unprecedented, regarding the power granted to minority shareholders to reject $\mathrm{RPTs}^{74}$. In its original form, section 188 of the Act mandated a MOM vote of shareholders through a special resolution, which required shareholders' approval holding $75 \%$ votes among those present and voting ${ }^{75}$. The rationale was that the concentrated shareholding in the hands of the promoters in India had enormous scope for potential abuse

72 Enriques \& Tröger, supra note 24, at 20.

73 OECD (2012), supra note 11, at 75; P. Srinivasan, An Analysis of RelatedParty Transactions in India, IIM Bangalore Research Paper No. 402 (2013).

74 M. Dhanush, Related Party Transactions Under the Companies Act, 2013 (2015). Available at SSRN: https://ssrn.com/abstract=2857182 or http://dx.doi.org/10.2139/ssrn.2857182.

$75 \S 188(1)$, second proviso, The Companies Act 2013, Acts of Parliament, 2013 (India); P. S. Velmurugan \& I.VK Mohammad, An Analysis of Corporate Governance Issues Arising Out of Related-Party Transactions: With Special Reference to NSE 200 Companies (2018). Available at SSRN: https:// ssrn.com/abstract=3095168 or http:/ /dx.doi.org/10.2139/ssrn.3095168. 
regarding RPT's ${ }^{76}$. Historically, India has had systematic problems with RPTs being abused by controlling shareholders (i.e. promoters); therefore, the legislator identified the latter's accountability to minority shareholders as the heart of the problem ${ }^{77}$.

However, the companies' representations advocated that such regulations were hampering business operations' efficiency because too cumbersome and often impractical to obtain ${ }^{78}$. Consequently, at first, the Ministry of Corporate Affairs ("MCA") through two circulars substantially diluted Section 188 of the Companies Act's provisions. The first circular narrowed the definition of a "Related party" for the purpose of voting on resolutions, enabling a large set of shareholders who are likely to benefit but are not "related" to vote on RPT resolutions. The second circular required to seek shareholder approval for only those RPTs which cross a certain threshold, and it exempted companies from seeking shareholder approvals for RPTs with whole subsidiaries 79 . Additionally, the 2015 Companies Amendment Act has established that RPTs only need shareholder approval through an "ordinary resolution", reducing the requirement to a simple majority vote (i.e., with the support of more than $50 \%$ votes among shareholders present and voting $)^{80}$. These moves have received acceptance from India's business community 81 , but they have further decreased the power of minority shareholders to block abusive RPTs. The problem has been worsened by India's challenges in enforcing corporate governance norms due to inadequate enforcement machinery available to the regulators and to an overburdened court system ${ }^{82}$. The result is that behind many corporate frauds there is still a strong role of related party

76 Dhanush, supra note 74.

77 M. Bertrand et al., Ferreting Out Tunneling: An Application to Indian Business Groups, 117 Q.J. ECON. 121 (2002).

78 Puchniak \& Varottil, supra note 46 , at 354.

79 Dhanush, supra note 74.

$80 \S 16$, The Companies (Amendment) Act 2015, No. 22, Acts of Parliament, 2019 (India).

81 Puchniak \& Varottil, supra note 46 , at 355.

82 U. Varottil, A Cautionary Tale of the Transplant Effect on Indian Corporate Governance, 21 Nat'1. L. Sch. Ind. Rev. 1, 30 (2009). 
transactions ${ }^{83}$. For this reason, the Securities and Exchange Board of India appointed a Working Group that on 27 January 2020 proposed a recommendation for strengthening the monitoring and enforcement of rules on RPTs ${ }^{84}$.

\subsection{The "political effect" on RPTs}

On one side, these interventions show that RPTs regulation is sensitive and reacts to the political pressures that arise after an economic crisis ${ }^{85}$. Populist reforms after a scandal or crisis are a typical "political effect" on corporate law. During and after a crisis, lawmakers feel strong from the electorate to implement reforms, so they respond by "doing something" for the sake of it rather than because something genuinely needs to be done. Moreover, their interventions' content is determined by what generally appeals, which may differ from what will solve the underlying economic problems. On the other side, they demonstrate that RPTs rules cannot be evaluated in isolation from the specific context in which they need to be applied or without considering the actual economic rationale behind them. The shareholders' approval mechanism has a solid theoretical foundation, and it is consistent with the political climate about the issue that followed the corporate scandals and the financial crisis. However, like any other a priori theoretical choice, it might lead to unsatisfactory results, not reach the planned targets, or even turn out to be harmful when it interacts with a given jurisdiction's contingent factors.

83 A. Kotoky, IndiGo's billionaire owners' feud over governance lapses heads to court, https://theprint.in/economy/indigos-owners-feud-over-headsto-court/300006/; A. Mandhani, All about related party transactions that are at the heart of IndiGo promoters' spat, https://theprint.in/theprintessential/all-about-related-party-transactions-that-are-at-the-heart-ofindigo-promoters-spat/266333/.

84 SEBI, Report of the Working Group on Related Party Transactions, (2020).

85 R. Romano, Regulating in the Dark, YALE LAW \& ECONOMICS RESEARCH PAPER No. 442 (March 30, 2012). Available at SSRN: https://ssrn.com/abstract=1974148 or http:// dx.doi.org/ 10.2139/ ssrn.1974148 (2016). 


\section{COVID-19 and Corporate Law}

SARS-CoV-2 (referred to also as COVID-19 or coronavirus) is first a human tragedy that has provoked an unprecedented public health crisis. At the same time, the pandemic has generated a significant economic crisis. With a halt in production and restrictions on a wide range of activities in many countries, travel bans, a collapse in consumption and confidence, and turmoil in stock exchanges, coronavirus has "frozen up" the economic activity, causing a massive contraction of the global economy. The International Monetary Fund has forecasted a $4.9 \%$ decline in global GDP in 2020, with considerable further downward risk ${ }^{86}$. Other commentators suggest a worse scenario where developed countries' GDP will drop by between 15 and 30\% within the last quarter of 2019 and the second quarter of $2020^{87}$.

COVID-19 is different from the previous crisis, representing a shock to the economy the likes of which no one has ever seen ${ }^{88}$. In contrast with the 2008 financial crisis, the coronavirus outbreak has not affected just isolated economic sectors, but it is threatening most of them, on both the supply and the demand sides ${ }^{89}$. On the supply side, there is a direct reduction in the supply of labour from unwell workers, from caregivers who have to take care of kids because of school closures, increased mortality, and workers who cannot work. An even larger effect on economic activity occurs because of the contagion containment measures, which have led to a drop in

86 International Monetary Fund, World Economic Outlook Update. A Crisis Like No Other, An Uncertain Recovery (2020).

${ }^{87}$ C. Mason, The Coronavirus Economic Crisis: Its Impact on Venture Capital and High Growth Enterprises, Publications Office of the European Union (J. Gavigan ed., 2020).

88 J. Furman, Protecting people now, helping the economy rebound later, MitigATING THE COVID ECONOMIC CRISIS: ACT FAST AND DO WHATEVER It TAKes, CENTRE For ECONOMIC POlicy Research (R. Baldwin \& B. Weder di Mauro eds., 2020).

${ }^{89} \mathrm{G}$. Gopinath, Limiting the economic fallout of the coronavirus with large targeted policies, in Mitigating the COVID Economic Crisis: Act Fast and Do Whatever It Takes, CENTRE FOR ECONOMIC POlicy RESEARCH (R. Baldwin \& B. Weder di Mauro eds., 2020). 
capacity utilization and have lowered production. Furthermore, supply chains get severed since firms that rely on them may have been unable to get the parts they need, whether domestically or internationally. Together, these disruptions have contributed to a rise in business costs and constitute a negative productivity shock, reducing economic activity. On the demand side, the loss of income, fear of contagion, heightened uncertainty, and the forced change in consumption patterns resulting from health-related measures make consumers and businesses spend less.

Moreover, most of the worst global recessions over the past six decades have been caused either by exogenous economic shocks or by severe financial sector problems that turned into banking crises. The COVID crisis does not originate from the financial sector, but it is spreading "from the bottom up". Banks, which in the 2008 global financial crisis were demonized for their irresponsible behavior, are not part of the problem, and to the contrary, they should be part of the solution ${ }^{90}$. Instead, the risk has migrated to the non-bank part of the financial system, namely, traditional investors such as pension funds, insurance, mutual funds, and newer investors such as hedge funds and private equity. Furthermore, differently from a "normal" recession, this crisis does not discriminate, since rather than simply clearing out less productive firms, it also results in the death of many good firms ${ }^{91}$. Eventually, both authorities and businesses have to deal with a considerably higher-than-usual degree of uncertainty around the forecasts, the pandemic itself, its macroeconomic fallout, and the associated stresses in financial and commodity markets ${ }^{92}$.

90 W. L. Megginson \& V. Fotak, Government Equity Investments in Coronavirus Bailouts: Why, How, When? (April 14, 2020). Available at SSRN: https://ssrn.com/abstract=3561282 or http:// dx.doi.org/ 10.2139/ ssrn.3561282.

91 Mason, supra note 87.

92 International Monetary Fund, A Crisis Like No Other. An Uncertain Recovery, World Economic Outlook Update, (2020); Robin Wigglesworth, Coronavirus Creates Biggest Economic Uncertainty in Decades, Financial Times, April 20, 2020. Available at: <https:// www.ft.com/ content/4d77ab77-0ff0-46ff-b30e-ae712c582457?shareType=nongift $>$. 


\subsection{Companies' Liquidity Shortfalls}

Companies' main issue is that the dramatic and sudden income loss has caused them severe liquidity shortages. The pandemic outbreak and related emergency measures implemented to tackle the health crisis have made it difficult for many enterprises to meet their financial obligations. Many of the fixed costs, like rents and interest payments, remain due, whereas the cash flow destined to meet these obligations has been severely impacted. As a result, many otherwise sound firms face acute liquidity problems that might eventually become solvency problems ${ }^{93}$. Nevertheless, it must be avoided that liquidity pressures evolve into solvency pressures because it would convert a temporary shock into a decline in long-run economic performance ${ }^{94}$. As it has been underlined, "the biggest threat to the economy is that viable businesses become illiquid and go bust"95.

Consistently, the focus of governments around the world has been on taking action to address companies' liquidity shortfalls. For example, they have introduced: insolvency relief tools to keep distressed firms out of formal insolvency proceedings or at least to delay them, gaining valuable time to facilitate the restructuring and corporate workouts ${ }^{96}$; allowances for deferred payments, rent reductions, interest rates reductions, and subsidy increases, tax relief

${ }^{93}$ OECD, National corporate governance related initiatives during the COVID-19 crisis, OECD Publishing (2020). H. Eidenmüller \& K. van Zwieten, COVID-19 and Beyond: The Case for Creditor Cooperation Duties in Corporate Workouts, in COVID-19 and Business Law, Verlag C.H.Beck oHG, 67 (H. Eidenmüller et al. eds., 2020).

94 P. R. Lane, The monetary policy package: An analytical framework, in Mitigating the COVID Economic Crisis: Act Fast and Do Whatever It Takes, CENTRE FOR ECONOMIC POLICY RESEARCH (R. Baldwin \& B. Weder di Mauro eds., 2020).

${ }_{95} \mathrm{C}$. Odendahl J. Springford, Bold policies needed to counter the coronavirus recession, in Mitigating the COVID Economic Crisis: Act Fast and Do Whatever It Takes, CENTRE FOR ECONOMIC POLICY RESEARCH (R. Baldwin \& B. Weder di Mauro eds., 2020).

${ }^{96}$ Eidenmüller van Zwieten, supra note, 93: "The policy rationale of these measures is to minimize the economic loss inflicted on firms by formal bankruptcy proceedings. For viable firms in particular, indirect bankruptcy costs can be huge, eliminating up to $20 \%$ of firm value". 
or a moratorium on debt repayments, to ease liquidity constraints97; temporary public guarantees for banking loans, that are playing a prominent role for ensuring businesses' access to finance amid the emergency ${ }^{98}$.

In the domain of corporate law, governments have enacted temporary amendments that, following a "survival first" imperative, provide for more flexible and speedy capital measures to keep companies afloat ${ }^{99}$. For example, some countries have stipulated that dividends can only be disbursed following a shareholders' in favour thereof. Moreover, regulators worldwide have called for a prudent approach to share buybacks as well, given the potential liquidity stress and the effects on internal and external stakeholders, due to the partial or complete stop of operations of many organizations. In some countries, to ease speedy recapitalization, the majority necessary for capital measures (capital increases, capital decreases, conditional, etc.) has been lowered, the acquisition of shares by funds has been allowed at terms lower than current market prices, and procedural terms have been shortened and lightened. Others have relaxed shareholders pre-emption rights on newly issued shares, shortening the time it takes to execute a capital increase resolution and attracting investors willing to prop up the company via an equity capital injection.

97 Y. Huang et al., Saving China from the coronavirus and economic meltdown: Experiences and lessons, in Mitigating the COVID Economic Crisis: Act Fast and Do Whatever It Takes, CENTRE FOR ECONOMIC POLICY RESEARCH (R. Baldwin \& B. Weder di Mauro eds., 2020).

98 G. Gobbi et al., Unintended effects of loan guarantees during the COVID-19 crisis, VoxEU.org., April 15, 2020.

99 D. A. Zetzsche et al., The COVID-19-Crisis and Company Law - Towards Virtual Shareholder Meetings, UNIVERSITY OF LUXEMBOURG FACULTY OF LAW, ECONOMICS \& FINANCE WPS 2020-007 (2020); L. Enriques, PandemicResistant Corporate Law: How to Help Companies Cope with Existential Threats and Extreme Uncertainty During the COVID-19 Crisis, EUROPEAN COMPANY AND FINANCIAL LAW REVIEW (Forthcoming), European Corporate Governance Institute - Law Working Paper No. 530/23020, (June 29, 2020). 


\section{RPTs Regulation during COVID-19}

Against this backdrop, suspension or relaxation of rules on related party transactions has been introduced.

\subsection{The United Kingdom}

On 8 April, in response to the COVID-19 crisis, the Financial Conduct Authority ("FCA") announced a series of temporary measures to help listed companies access capital through equity fundraisings 100 . They also cover alternatives to general meeting approval for related party transactions, recognizing that during the pandemic there are several challenges for companies in convening a general meeting that could jeopardize their ability to complete critical fundraising quickly. To help address those challenges, the FCA has modified the Listing Rules' application so that premium listed companies can apply to the FCA for dispensation from the requirement to hold a general meeting where shareholder approval is required for related party transactions. To receive the dispensation, issuers need to have obtained written undertakings from shareholders that they approve the proposed transaction and would vote in favour of a resolution to approve the transaction if a general meeting were to be held. Moreover, issuers need to obtain a sufficient number of undertakings to meet the relevant threshold for obtaining shareholder approval. Finally, when the requisite number of written undertakings is obtained, the issuer must inform the market.

Even though the measures on RPTs do not go as far as it was hoped, they still provide some additional flexibility to companies who need to raise additional funding to shore up their balance sheet because of the crisis ${ }^{101}$.

100 FCA, Statement of Policy: listed companies and recapitalisation issuances during the coronavirus crisis, April 8, 2020.

101 T. Smith, Listed companies: FCA equity fundraising measures, Corporate and M\&A, Corporate Advisory, April 14, 2020. 


\subsection{The United States}

In the US, the Securities and Exchange Commission ("SEC") has temporarily waived or suspended specific rules ${ }^{102}$, reflecting the New York Stock Exchange's ("NYSE") expectation that many listed companies need to access additional capital that may not be available in the public equity or credit markets.

Particularly, to meet the growing liquidity needs caused by COVID19, the SEC approved new temporary Section 312.03T of the NYSE Listed Company Manual, allowing NYSE-listed companies - from 14 May 2020, through 30 June 2020, and subject to specified conditions - to issue securities to related parties (i.e. officers, directors, employees, and consultants) without shareholder approval.

The rule facilitates the quick raising of capital during the pandemic from individual investors or small groups of investors, including existing shareholders and related parties ${ }^{103}$.

\subsection{Italy}

In Italy, Consob - which is the public authority responsible for regulating the Italian financial markets - has amended its regulation on related party transactions for listed companies, temporarily broadening the scope of provision relaxing procedural requirements in the presence of urgency reasons ${ }^{104}$. Namely, it provides that the special regime for the urgent transaction shall apply by default rather than by opt-in via a corporate charter clause to facilitate the

102 Securities and Exchange Commission, release no. 34-88572, file no. SRNYSE-2020-30 (Apr. 6, 2020); Securities and Exchange Commission, release no. 34-88875, file no. SR-NYSE-2020-43 (May 14, 2020).

103 Zetzsche et al., supra note 99.

${ }^{104}$ Commissione Nazionale per le Società e la Borsa (CONSOB), Resolution n. 21396 of 10 June 2020, Temporary suspension of the application of some provisions of the Regulation adopted with Resolution 17221/2010 and subsequent amendments on related party transactions (RPT) to facilitate the use of the exclusion option in cases of urgency by companies with shares listed on regulated markets and by companies with shares widely distributed among the public. 
exemption option in urgent capital strengthening operations involving related parties.

More in details, the option (already provided for by the regulations in force since 2011) allows companies on the reasons of urgency to derogate from the procedural requirements for the approval of RPTs, provided that adequate public information is given on the transaction and that shareholders are allowed to express themselves on the transaction during the first helpful meeting. Yet, the Consob regulation requires companies to provide in advance for the exemption in the case of urgent transactions both in the articles of company statutes and in the procedures for carrying out RPTs. The resolution adopted in response to COVID-19 makes it possible until 30 June 2021 to use the provisions expressly dictated for urgent cases by companies that have not provided for this option in their procedures and/or in their articles of association. According to Consob, the simplification intervention could affect more than $60 \%$ of the companies currently listed, which have not provided for the exemption in the case of urgency or have provided for it only partially (only for operations about the administrative or delegated body or only for those about shareholders) ${ }^{105}$. Since in the event of operations falling within the competencies of the shareholders' meeting the implementation of the mentioned exemption is possible only in cases of urgency "connected to corporate crises", Consob has also specified that, until 30 June 2021, the need to deal with emergency cases related to the pandemic sets up an emergency case related to corporate crises ${ }^{106}$.

Besides, the "Liquidity Decree" (released 8 April 2020 and converted into Law no. 40, dated 5 June 2020) has suspended - between 9 April 2020 and 31 December 2020 - the corporate law provisions on equity subordination for shareholders' loans and loans granted by entities exercising management and coordination activities. Under Article

105 Commissione Nazionale per le Società e la Borsa (CONSOB), Press Release. COVID-19: Related party regulation, Consob simplifies the use of the exemption in the case of urgent capital strengthening operations, June 12, 2020. 106 Commissione Nazionale per le Società e la Borsa (CONSOB), Communication n. 6/2020 of 11 June 2020. 
2467 and 2497-quinquies, the Italian civil code sets out a general rule (extensively applied by courts) of equitable subordination of loans made by shareholders and intra-group loans. More in details, the articles provided that loans granted by shareholders and/or by other group companies under centralized "management coordination activity" are subordinated to the repayment of the other creditors if at the time the loan is advanced there is an imbalance between the company's indebtedness and its net asset value, or the company's financial situation would require an equity contribution instead of a loan. The rule is aimed at discouraging the so-called undercapitalization of companies. Yet, in the current situation where enterprises need new finance, such a mechanism represented a significant disincentive for shareholders that are likely to be the most immediate funding entities. The provision of the Liquidity Decree thereby incentivizes shareholders' injection of fresh financial resources into companies.

\subsection{RPTs' as an Instrument for Propping Companies during COVID-19}

Under Section 3 we have seen how, after the 2008 crisis, lawmakers have generally introduced and tightened rules on related party transactions, particularly to enhance minority shareholders' protection.

Instead, the exemptions to RPTs rules enacted during the COVID-19 pandemic might decrease shareholders' oversight of RPTs, while increasing the risk of expropriation by the controllers to the detriment of minority shareholders.

Notwithstanding, these exemptions can facilitate the channel of funding to distressed companies that are facing a severe liquidity shortage. As explained above, there are situations in which controlling shareholders are in the best position to provide cheap finance to an ailing firm. The suspension or relaxation of rules on RPTs that considerably lengthen the decision-making process or that support recapitalization of firms using shareholders' loans gives the controllers an incentive to "prop up" their distressed companies. When the need for liquidity is urgent, and the avoidance of a wave 
of insolvencies is in the public interest ${ }^{107}$, these kinds of exemptions about RPTs can be encouraged, even at the cost of intensifying the risk of abuse ${ }^{108}$. In other words, in a "survival first" mode, it seems acceptable to sacrifice a tool for the minority shareholders' protection to keep companies afloat.

In the trade-off between curbing tunnelling via RPTs and allowing propping via RPTs, corporate law scholarship generally focuses on the need to protect minority shareholders from controller opportunism. Yet, effective regulation of RPTs must also include strategies for preserving the advantages deriving from valuecreating RPTs. The right balance between the two goals crucially depends on the economic environment. Hence, any severe crisis or significant economic event triggers a response in RPTs regulation, which has to be tailor-made as each crisis is different.

As Figure 1 illustrates graphically, the 2008 crisis and the COVID-19 crisis pose different issues concerning RPTs, which justify different kind of interventions.

In 2008, corporate governance failures were among the causes of the crisis, while they have nothing to do with the COVID-19 outbreak. After the global financial crisis, governments enacted regulations aimed at preventing a future crisis. With respect to RPTs, this meant designing rules for preventing tunnelling and increasing minority shareholders' protection. During COVID-19 instead, lawmakers are laying out interventions for resolving the crisis, addressing the central problem the pandemic is provoking to businesses: lack of liquidity. Therefore, the exemptions to the current RPTs regulations are directed to incentivize controllers to prop up their companies through RPTs.

107 T. Custer, COVID-19 and the Bankruptcy Court Workload, 19 May 2020, https://blogs.harvard.edu/bankruptcyroundtable/2020/05/19/COVID -19-and-the-bankruptcy-court-workload/; Eidenmüller van Zwieten, supra note 93.

${ }^{108}$ Enriques (2020), supra note 99. 
2008 financial crisis

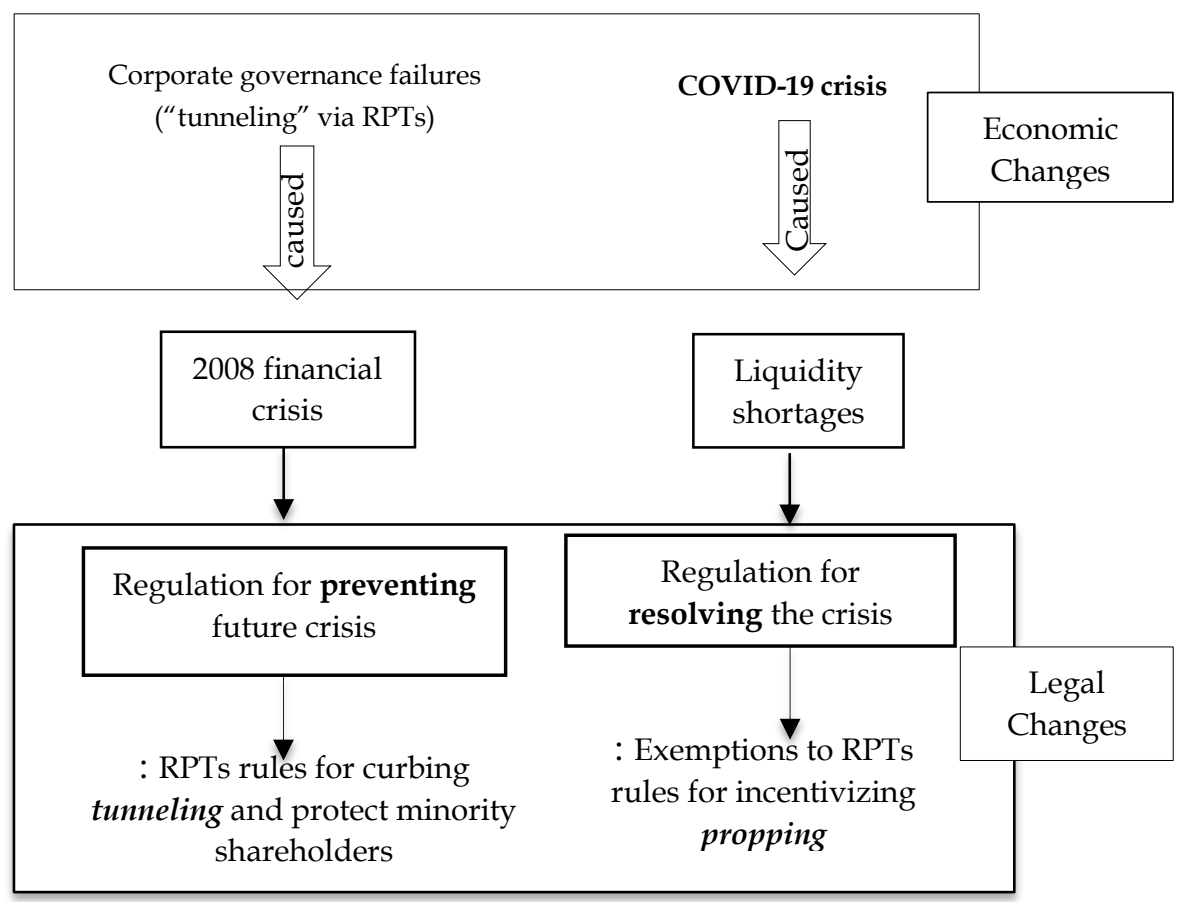

Figure 1

However, these exemptions are examples of temporary corporate law interventions for countering the emergency ${ }^{109}$, and this has some implications. First, adopting company law measures during a crisis requires some caution. It is better to opt for the simplest form of intervention, such as regulatory exemption or waiver powers, and to provide flexibility in implementation. The rule tweaks should be proportionate, deviating from the corporate law that applies in normal conditions as slight as possible. Emergency measures should have a clear and reasonable end date, allowing to duly ponder the need to extend their validity and to reduce the risk of them staying

${ }^{109}$ Enriques (2020), supra note 99. 
in force for longer than needed ${ }^{110}$. Second, these are emergency corporate law rules enacted to allow companies to survive. Hence, the same rules could play out differently in normal times, becoming ineffective or even counterproductive. Thereby, once the liquidity crisis prompted by the pandemic is over, it will be necessary to discuss the merits of the emergency corporate law rules again, likely going back to regular times protections or anyway adapting them to the new economic scenario.

\section{Conclusion}

A lesson for the future to be learned from the current pandemic emergency is the positive contribution RPTs can give during a liquidity crisis. When - as during COVID-19 - banks are reluctant to lend to firms due to the probability of default and the likely deterioration underway in their balance sheets 111 , and there is a significant contraction in the supply of equity capital as well ${ }^{112}$, RPTs can provide a liquidity lifeline. Financing from the controllers can create significant advantages by supporting those firms that could otherwise find it difficult to attract external funding and by lowering the cost of raising capital113. Consequently, even if a certain level of expropriation is anticipated, the dominant shareholder's finance can still be an optimal choice due to its offsetting benefits, which are especially advantageous when facing a dramatic liquidity shortfall.

Moreover, when the controlling shareholder is a "stationary controller", it usually has a long-term interest in the controlled corporation. Therefore, it is in its own best interest to voluntarily reduce the degree of expropriation from minority shareholders ${ }^{114}$. Beyond COVID-19, the incidence of RPTs is significantly affected (among other things) by the existing share ownership structure and

${ }^{110}$ Enriques (2020), supra note 99.

${ }^{111} \mathrm{~J}$. Galì, Helicopter money: The time is now, in Mitigating the COVID Economic

Crisis: Act Fast and Do Whatever It Takes, CENTRE FOR ECONOMIC POLICY

RESEARCH (R. Baldwin \& B. Weder di Mauro eds., 2020).

112 Mason, supra note 87.

113 Masulis et al., supra note 21.

114 Kang, supra note 12. 
by the economic environment. In most jurisdictions around the world, the ownership of shares is concentrated in controlling shareholders' hands. Thus, when the economic downturns result in a credit crunch from the banking system and a decline in equity finance, the controlling shareholder's funds might be the only viable solution.

As noted above, usually the focus of corporate law doctrine and policy is almost exclusively on protecting investors from controllers' agency costs, namely controllers' self-dealing. Instead, in times of economic stress it is right to incentivize the financing transactions with the controllers, even if this requires courts and lawmakers to tolerate some level of self-dealing. Then, if there is any form of abuse, it is preferable to deal with it by ex post review - including liability suits for the breach of directors' duty of loyalty - than making the funding excessively burdensome and time-consuming ex ante ${ }^{115}$. In short, there is an inevitable trade-off between minority protection and controller rights ${ }^{116}$, and the optimal balance changes with the economic scenario.

To conclude, in dealing with RPTs, it is essential to acknowledge the strong interdependency of RPTs regulation with economic development. More broadly, the law has a rolling relationship with the economy, as they constantly react to one another ${ }^{117}$. On one side, each crisis prompts institutional reactions, and the law should continuously adapt and respond to changes in the economy ${ }^{118}$. Not only does the economy functions differently in deep recessions than in ordinary times, but the laws also cause one set of effects in deep recessions and a different set of effects other times ${ }^{119}$. On another

115 Enriques (2020), supra note 99.

116 Goshen \& Hamdani, supra note 11, at 44 .

117 C. J. Milhaupt, \& K. Pistor, Law and Capitalism: What Corporate Crises Reveal about Legal Systems and Economic Development around the World, THE UNIVERSITY OF CHICAGO PRESS, 219 (2008).

118 Y. Listokin, Law and Macroeconomics: The Law and Economics of Recessions, Yale Law School, Public Law Research Paper No. 576 (2016). ${ }^{119} \mathrm{Id}$. 
side, the law is essential to economic development, and it can affect economic outcomes ${ }^{120}$.

RPTs regulation during a crisis reflects this highly iterative process of action and strategic reaction with economic changes. The COVID19 crisis, in particular, has highlighted how the rules on RPTs do not have the function of protecting outsiders' rights solely, but they can also play a role in support of economic activity. Therefore, RPTs regulation should be structured in a flexible way to achieve both of these roles and to shift from one to another as the economy changes.

${ }^{120}$ R. D. Cooter et al., The Importance of Law in Promoting Innovation and Growth, The Kauffman Task Force on Law, Innovation, and Growth, Rules for Growth. Promoting Innovation and Growth through Legal Reform (Kauffman Foundation, 2011). 